\title{
Relationship between lactate level and length of hospital stay in patients with a COPD exacerbation
}

\section{Seda Beyhan Sagmen ${ }^{1}$, Tugba Naziroglu ${ }^{2}$ \\ ${ }^{1}$ Department of Pulmonary Medicine, Kartal Dr. Lutfi Kirdar Training and Research Hospital, University of Health Sciences, Istanbul, Turkey \\ ${ }^{2}$ Department of Pulmonary Medicine, Bingol State Hospital, Bingol, Turkey}

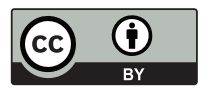

This work is licensed under a Creative Commons Attribution 4.0 International License

Received: 2020-01-22

Accepted: 2020-05-01

UDC: 618.1

\section{J Clin Med Kaz 2020; 3(57):19-23}

Corresponding author: Seda Beyhan Sagmen, Department of Pulmonary Medicine, Kartal Dr. Lutfi Kirdar Training and Research Hospital, University of Health Sciences, Istanbul, Turkey. Tel.: +905054912596 E-mail: sedabeyhansagmen@gmail.com

\section{ABSTRACT}

Objective: To investigate the effect of lactate levels on length of hospital stay in patients with chronic obstructive pulmonary disease exacerbation.

Material and methods: Patients who were hospitalized for chronic obstructive pulmonary disease exacerbation between October 2017 and December 2018 were evaluated. Those who had pneumonia or any other additional disease that might affect the lactate level during hospitalization were excluded from the study. The arterial blood gas parameters and lactate levels measured at the time of hospitalization were examined. The patients were divided into two groups according to the length of stay: longer than seven days and shorter than seven days. The relationship of lactate levels with the length of hospital stay and requiring non-invasive mechanical ventilation during hospitalization was investigated.

Results: A total of 101 patients, 28 females (27.72\%) and 73 males (72.28\%), participated in the study. The mean age of the patients was $68 \pm 9$ years. Fifty-seven (56.44\%) patients were hospitalized for 7 days or less and 44 patients $(43.56 \%)$ were hospitalized for more than 7 days. The mean length of hospital stay was $7.37 \pm 2.24$ days. An examination of the relationship between lactate and length of hospital stay revealed a significant correlation $(\mathrm{p}<0.001$; $\mathrm{r}=0.791$ ). When the patients were divided into two groups according to their length of hospital stay, lactate levels were found to be higher in patients who were hospitalized for longer than seven days $(2.74 \pm 0.74)$ compared with patients who were hospitalized for seven days or less $(1.50 \pm 0.58)(\mathrm{p}<0.001)$. The body mass index of patients hospitalized for longer than seven days was found to be lower than in the patients hospitalized for seven days or less $(\mathrm{p}<0.001)$. The lactate levels of the patients requiring non-invasive mechanical ventilation were found to be higher $(2.29 \pm 0.91)$ than the other patients $(1.70 \pm 0.76)(p=0.001)$. A determinative cut-off point was examined for the lactate level in hospitalizations of patients. When the lactate value was taken as $1.95,90.91 \%$ sensitivity and $84.21 \%$ specificity were obtained.

Conclusion: Lactate levels may become important in clinical practice to predict the duration of hospitalization because it can be measured quickly and easily.

Key words: lactate, chronic obstructive pulmonary disease, length of hospital stay, non-invasive mechanical ventilation

ӨСОА АСҚЫНҒАН ПАЦИЕНТТЕРДЕ ЛАКТАТ ДЕНГЕЙІ ЖӘНЕ ЕМДЕЛУГЕ ЖАТУ ҰЗАҚТЫҒЫНЫН

АРАСЫНДАҒЫ ӨЗАРА БАЙЛАНЫС

С.Б. Сагмен ${ }^{1}$, Т. Назироглу

'Өкпе медицинасы бөлімі, Картал ауданының Доктор Лутфи Кирдар атындағы оку-зерттеу ауруханасы, Ыстамбұл, Түркия

${ }^{2}$ Өкпе медицинасы бөлімі, Бингёль қ. Мемлекеттік ауруханасы, Ыстамбұл, Түркия

\section{ТҰЖЫРЫМДАМА}

Мақсаты: ӨСОА асқынған пациенттерде лактат деңгейінің емделуге жату ұзақтығына әсерін зерттеу.

Материалдары және әдістері: 2017 жылдың қана айы мен 2018 жылдың желтоқсан айы аралығында өкпенің созылмалы обструктивті ауруы асқынып, емделуге жатқызылған пациенттер зерттелді. Емделуге жатқызылған кезде пневмониясы бар немесе лактаттың деңгейіне әсер етуі мүмкін басқа да ауруы бар пациенттер зерттеуден алып тасталды. Госпитализация кезінде өлшенген артериальды газдың деңгейі және лактат деңгейі зерттелді. Пациенттер болу ұзақтығына байланысты екі топқа бөлінді: жеті күннен көп және жеті күннен аз. Лактат деңгейінің ауруханада болу ұзақтығы мен ауруханаға жатқанда өкпені инвазивті емес механикалық желдету қажеттілігі зерттелді. 
Нәтижелері: Зерттеуге барлығы 101 пациент қатысты, 28 әйел (27,72\%) және 73 ер адам (72,28\%). Пациенттердің орташа жасы $68 \pm 9$ жас. Елу жеті (56,44\%) пациент 7 күннен немесе одан аз уақытқа ауруханаға жатқызылды, ал 44 науқас $(43,56 \%) 7$ күннен артық ауруханаға жатқызылды. Ауруханада болудың орташа ұзақтығы 7,37 $\pm 2,24$ күнді құрады. Лактат пен ауруханада болу ұзақтығының арақатынасын зерттеу айтарлықтай корреляцияны көрсетті ( $<<0.001 ; r=0.791)$. Науқастар ауруханада болу ұзақтығына қарай екі топқа бөлінгенде, жеті күн немесе одан аз уақыт ауруханаға жатқызылған $(1.50 \pm 0.58)(p<0.001)$ емделушілермен салыстырғанда, жеті күннен $(2,74 \pm 0,74)$ ауруханаға жатқызылған емделушілерде лактат деңгейі жоғары екендігі анықталды..

Жеті күннен артық ауруханаға жатқызылған науқастардың дене салмағының индексі жеті күн немесе одан аз уақытқа ауруханаға жатқызылған науқастарға қарағанда төмен екендігі анықталды ( $p<0.001)$. Инвазивті емес механикалық желдетуді қажет ететін пациенттерде лактат деңгейі басқа емделушілерге қарағанда $(2.29 \pm 0.91)$ жоғары $(1,70 \pm 0,76)(p=0.001)$ екендігі анықталды. Деректерді жинаудың аяқталу нүктесі ауруханаға жатқызылған науқастардағы лактат деңгейіне қатысты зерттелді. Лактат мәні 1,95 деп қабылданғанда, 90,91\% сезімталдығы және 84,21\% ерекшелігі алынды.

Қорытынды: Лактат деңгейлері емдеуге жату ұзақтығын болжау үшін линикалық тәжірибеде маңызды болуы мүмкін, өйткені оларды жылдам және жеңіл өлшеуге болады.

Негізгі сөздер: лактат, өкпенің созылмалы обструктивті ауруы, емдеуге жату ұзақтығы, өкпені инвазивті емес жасанды желдету

\section{ВЗАИМОСВЯЗЬ МЕЖДУ УРОВНЕМ ЛАКТАТА И ДЛИТЕЛЬНОСТЬЮ ГОСПИТАЛИЗАЦИИ У ПАЦИЕНТОВ С} ОБОСТРЕНИЕМ ХОБЛ

\section{С.Б. Сагмен ${ }^{1}$, Т. Назироглу}

'Отделение легочной медицины, Учебно-исследовательская больница им. Доктора Лутфи Кирдар района Картал, Стамбул, Турция

${ }^{2}$ Отделение легочной медицины, Государственная больница г. Бингёль, Стамбул, Турция

\section{PEЗЮME}

Цель: Изучить влияние уровня лактата на длительность госпитализации у пациентов с обострением хронической обструктивной болезни легких.

Материалы и методы: Обследованы пациенты, которые были госпитализированы с обострением хронической обструктивной болезни легких в период с октября 2017 года по декабрь 2018 года. Пациенты с пневмонией или любым другим дополнительным заболеванием, которое могло повлиять на уровень лактата во время госпитализации, были исключены из исследования. Были исследованы параметры газов артериальной крови и уровни лактата, измеренные во время госпитализации. Пациенты были разделены на две группы в зависимости от продолжительности пребывания: более семи дней и менее семи дней. Была исследована связь уровней лактата с длительностью пребывания в стационаре и необходимостью неинвазивной искусственной вентиляции легких во время госпитализации.

Результаты: Всего в исследовании приняли участие 101 пациент, 28 женщин $(27,72 \%)$ и 73 мужчины $(72,28 \%)$. Средний возраст

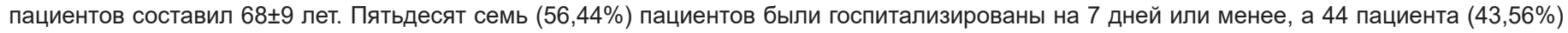

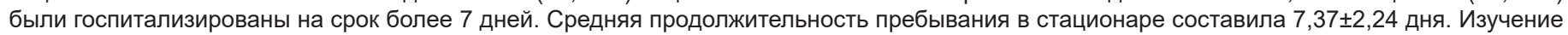
взаимосвязи между лактатом и длительностью пребывания в стационаре выявило значительную корреляцию ( $p<0.001 ; r=0.791)$. Когда пациенты были разделены на две группы в соответствии с продолжительностью их пребывания в стационаре, было обнаружено, что уровни лактата были выше у пациентов, которые были госпитализированы на срок более семи дней $(2,74 \pm 0,74)$, по сравнению с пациентами, которые были госпитализированы на семь дней или менее $(1.50 \pm 0.58)(p<0.001)$. Было установлено, что индекс массы тела пациентов, госпитализированных более семи дней, ниже, чем у пациентов, госпитализированных в течение семи дней или менее $(p<0.001)$. Установлено, что уровни лактата у пациентов, которым требуется неинвазивная искусственная вентиляция легких, выше $(2,29 \pm 0,91)$, чем у других пациентов (1.70 \pm 0.76$)(\mathrm{p}=0.001)$. Определяющая точка завершения сбора данных была исследована для уровня лактата при госпитализации пациентов. Когда значение лактата принималось равным 1,95, была получена чувствительность 90,91\% и специфичность 84,21\%.

Заключение: Уровни лактата могут стать важными в клинической практике для прогнозирования продолжительности госпитализации, потому что их можно измерить быстро и легко.

Ключевые слова: лактат, хроническая обструктивная болезнь легких, продолжительность госпитализации, неинвазивная искусственная вентиляциия легких

\section{Introduction}

Chronic obstructive pulmonary disease (COPD) is characterized by permanent airflow restriction due to airway and/ or alveolar abnormalities caused by serious exposure to harmful particles or gases. It is a common, preventable, and treatable disease that presents with respiratory symptoms. Exacerbation of COPD has been described as an acute worsening of respiratory symptoms, resulting in the need for additional treatment [1]. Exacerbations adversely affect the health status, hospitalization, and also the course of the disease [2,3]. During exacerbations of COPD, symptoms usually resolve over seven or 10 days, but in some cases, the duration may be prolonged. If the recovery of exacerbations is slow, disease is likely to worsen [4]. Factors associated with poor prognosis in COPD exacerbations include advanced age, low body mass index (BMI), presence of additional diseases such as cardiovascular disease or lung cancer, previous hospitalization due to COPD exacerbation, and long-term oxygen requirement after discharge. The following factors carry an increased risk of mortality for patients with COPD: increased and severe respiratory symptoms after an exacerbation, poor quality of life, poor pulmonary functions, low exercise capacity, and low lung density or increased airway wall thickness on computed tomography $(\mathrm{CT})$ of the thorax [1].

Lactate is produced by reduction of pyruvate with the enzyme lactate dehydrogenase in the human body [5]. In cases of hypoperfusion and hypoxia, pyruvate oxidation decreases and lactate production increases and passes into the bloodstream [6].
Lactate levels are thought to be an indicator of organ dysfunction and mortality [7]. In a study of patients presenting to the emergency department (ED) with acute COPD exacerbation, the relationship between lactate and lactate clearance was investigated to determine hospitalization or discharge. There was no difference between the hospitalized and discharged patients in terms of initial lactate levels; however, lactate clearance was found to be higher in patients who were discharged, whereas it was lower in hospitalized patients [8]. Although the relationship of lactate levels with mortality and length of hospital stay (LOS) was investigated in critical situations such as sepsis, shock, trauma, respiratory failure, or cardiac operation $[9,10,11]$, the role of lactate in COPD exacerbation is not fully known. The aim of this study was to investigate the relationship between lactate levels and LOS in patients hospitalized for COPD exacerbation, and whether we could use them as a prognostic indicator.

\section{Material and methods Patient selection}

A total of 130 patients hospitalized for COPD exacerbation between October 2017 and December 2018 in the Chest Diseases Clinic of our hospital were selected for the study. Written informed consent was obtained from the patients. A total of 29 patients were excluded from the study due to the presence of conditions affecting lactate levels: 15 patients due to pneumonia, eight patients due to known active malignancy, three patients due to renal failure, 
two patients due to liver failure, one patient due to a history of trauma, and one patient due to the use of metformin. The study was completed with a total of 101 patients. Age, sex, height, weight, BMI, long-term oxygen therapy requirement, comorbidities, need for non-invasive mechanical ventilation (NIMV), pulmonary function parameters (FEV1/FVC, FEV1, FEV1, FVC, FVC), and arterial blood gas parameters $(\mathrm{pH}, \mathrm{pCO} 2, \mathrm{pO} 2, \mathrm{HCO} 3, \mathrm{SO} 2$, lactate level) were recorded. Lactate levels of patients were measured on admission. The patients were divided into two groups according to their LOS: $>7$ days and $<7$ days. The lactate levels and need for NIMV of the two groups were evaluated.

\section{Statistical analysis}

Statistical analysis was performed using the SPSS version 17.0 software. Histogram graphs and the Kolmogorov-Smirnov test were used to determine whether the variables showed normal distribution. Mean and standard deviation values were used when presenting descriptive analyses. Comparisons were made using Pearson's Chi-square and Fisher's exact tests. The independent t-test was used for inter-group evaluations of parametric variables, and the Mann- Whitney U test was used for inter-group evaluations of non-parametric variables. Spearman's correlation test was used to analyse the relationships of measurable data. Lactate thresholds were examined in terms of predicting the LOS and were presented with sensitivity, specificity, positive predictive value (PPV), and negative predictive value (NPV). Furthermore, receiver operating characteristic (ROC) curve analysis was performed to determine the lactate threshold. The Youden index (j) was used. A p value of $<0.05$ was considered statistically significant.

\section{Results}

A total of 101 patients, 28 females (27.7\%) and 73 males (72.3\%), participated in the study. The mean age of the patients was $68 \pm 9$ years. Of the patients hospitalized due to COPD exacerbation, $57(56.4 \%)$ stayed at the hospital for $\leq 7$ days and 44 patients (43.6\%) were hospitalized for $>7$ days. The mean length of hospital stay was $7.37 \pm 2.24$ days. The demographic characteristics of the patients are presented in Table 1.

The examination of the relationship between lactate levels and LOS revealed a significant correlation $(\mathrm{p}<0.001 ; \mathrm{r}=0.791)$.

Table 1

Demographic characteristics of patients

\begin{tabular}{|c|c|c|c|}
\hline & Length of stay $\leq 7$ days & Length of stay $>7$ days & $\mathrm{p}$ value \\
\hline Age (years) & $67.96 \pm 8.78$ & $68.14 \pm 9.60$ & 0.926 \\
\hline $\operatorname{Sex}(M / F)$ & $43(75.4 \%) / 14(24.6 \%)$ & $30(68.2 \%) / 14(31.8 \%)$ & 0.419 \\
\hline BMI, kg/m2 & $26.53 \pm 4.59$ & $24.05 \pm 3.94$ & 0.041 \\
\hline $\begin{array}{l}\text { Long-term oxygen } \\
\text { treatment }\end{array}$ & $19(33.33 \%)$ & $19(43.18 \%)$ & 0.311 \\
\hline Coexisting Disease & $15(26.32 \%)$ & $15(34.09 \%)$ & 0.396 \\
\hline FEV1/FVC ratio & $52.00 \pm 12.68$ & $50.36 \pm 11.79$ & 0.509 \\
\hline FEV1 predicted (\%) & $41.60 \pm 14.01$ & $40.82 \pm 13.73$ & 0.781 \\
\hline FEV1 (L) & $1.07 \pm 0.46$ & $1.09 \pm 0.47$ & 0.766 \\
\hline FVC predicted (\%) & $58.96 \pm 17.31$ & $60.09 \pm 16.81$ & 0.743 \\
\hline FVC (L) & $1.89 \pm 0.66$ & $1.91 \pm 0.54$ & 0.909 \\
\hline Requiring NIMV & $25(43.86 \%)$ & $34(77.27 \%)$ & 0.001 \\
\hline $\mathrm{pH}$ & $7.38 \pm 0.07$ & $7.36 \pm 0.06$ & 0.151 \\
\hline $\mathrm{PCO} 2(\mathrm{mmHg})$ & $56.53 \pm 12.78$ & $58.34 \pm 14.39$ & 0.511 \\
\hline PO2 (mmHg) & $61.59 \pm 19.70$ & $63.89 \pm 21.21$ & 0.466 \\
\hline SO2 (\%) & $86.94 \pm 12.10$ & $87.64 \pm 9.27$ & 0.989 \\
\hline $\mathrm{HCO} 3(\mathrm{mmol} / \mathrm{L})$ & $29.53 \pm 9.12$ & $27.99 \pm 3.26$ & 0.661 \\
\hline Lactate $(\mathrm{mEq} / \mathrm{L})$ & $1.50 \pm 0.58$ & $2.74 \pm 0.74$ & $<0.001$ \\
\hline
\end{tabular}

FVC: Forced vital capacity; FEV1: Forced expiratory volume in $1 \mathrm{~s}$; BMI: Body mass index;NIMV: Non-invasive mechanical ventilation, pH-negative log of the Hydrogen ion concentration; p02: partial pressure of oxygen; pCO2: partial pressure of carbon dioxide; HCO3:concentration of bicarbonate ion; SO2: oxygen saturation

Figure 1 - Lactate level according to length of hospital stay

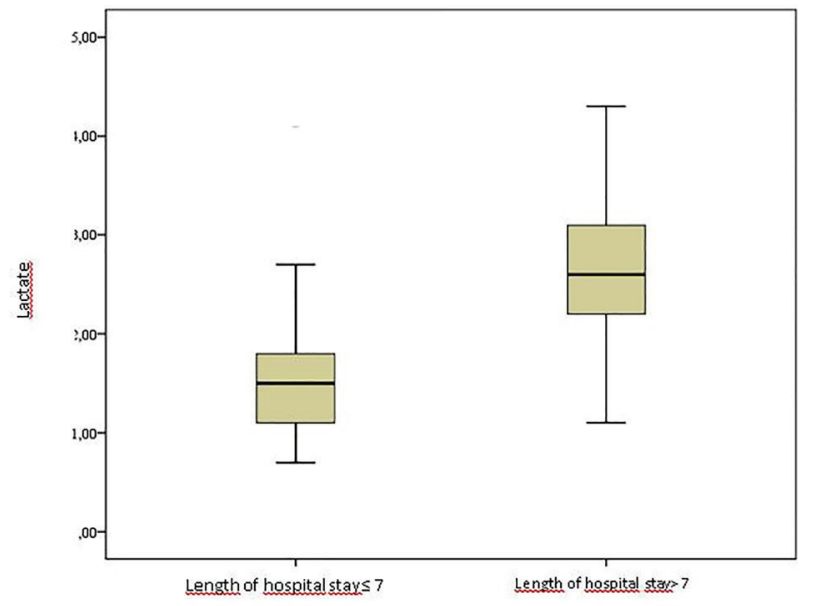

Figure 2 - ROC curve

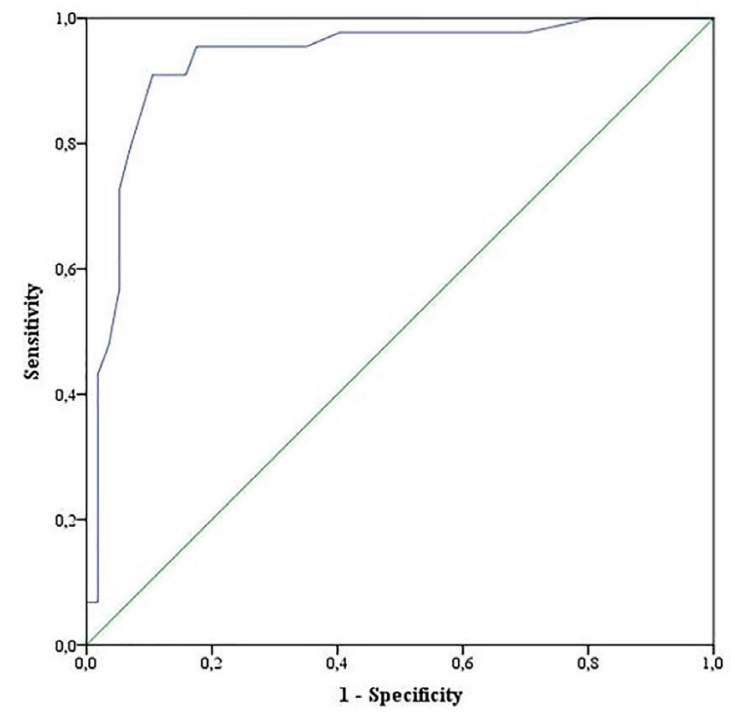




\begin{tabular}{|l|l|l|l|}
\hline & $\begin{array}{l}\text { Non-invasive mechanical } \\
\text { ventilation (+) }\end{array}$ & $\begin{array}{l}\text { Non- invasive mechanical } \\
\text { ventilation (-) }\end{array}$ & P value \\
\hline Lactate $(\mathrm{mEq} / \mathrm{L})$ & $2.29 \pm 0.91$ & $1.70 \pm 0.76$ & 0.001 \\
\hline
\end{tabular}

Table 3 Lactate level to predict length of hospital stay

\begin{tabular}{|l|l|l|l|l|}
\hline & Sensitivity & Specificity & PPD & NPD \\
\hline Lactate: 1.95 & $90.91 \%$ & $84.21 \%$ & $81.63 \%$ & $92.31 \%$ \\
\hline
\end{tabular}

When the patients were divided into two groups according to their LOS, blood lactate levels were found to be higher in patients who were hospitalized for $>7$ days $(2.74 \pm 0.74)$ compared with patients who were hospitalized $\leq 7$ days $(1.50 \pm 0.58)(p<0.001)$ (Figure 1). The BMI values of patients hospitalized for $>7$ days were found to be lower than the patients hospitalized for $\leq 7$ days $(\mathrm{p}<0.001)$.

The blood lactate levels of patients who needed NIMV in addition to medical therapy during COPD exacerbation therapy $(2.29 \pm 0.91)$ were found to be higher than those who did not need NIMV $(1.70 \pm 0.76)(p=0.001)$ (Table 2).

LOS $>7$ days in patients who required NIMV (57.63\%) was found to be statistically significantly higher than those who did not require NIMV (23.81\%) ( $\mathrm{p}=0.001)$. The rate of long-term oxygen therapy use was found to be higher in patients who required NIMV $(49.15 \%)$ than in those who did not require NIMV $(21.43 \%)$ $(\mathrm{p}=0.005)$.

A cut-off point was determined by calculating the sensitivity and specificity of the blood lactate levels through ROC analysis to estimate its relationship with patients' LOS (Figure 2). When the lactate value was taken as $1.95,90.9 \%$ sensitivity and $84.2 \%$ specificity were obtained (Table 3 ).

\section{Discussion}

Blood lactate levels of patients hospitalized due to COPD exacerbation were found to be significantly higher in patients with a LOS of longer than seven days than those who were hospitalized for seven days or less. Blood lactate levels of patients who required NIMV during COPD exacerbation therapy were found to be significantly higher than in those who did not require NIMV.

The level of lactate in the body reflects tissue hypoperfusion and hypoxemia. In critical cases, an increase is observed in lactate levels before hemodynamic disorders occur. This is thought to be an early marker of organ dysfunction or mortality. In a study on patients admitted to the ED due to COPD exacerbation, hospitalized and discharged patients were compared and no difference was found between the patients in terms of initial blood lactate levels. In the same study, a significant difference was found between patients with COPD hospitalized or discharged in terms of lactate clearance [12]. The relationship between the LOS and blood lactate levels has been examined in many critical situations in the literature. To the best of our knowledge, this is the first study to investigate lactate levels and LOS in COPD exacerbations.

When the relationship between the LOS and blood lactate levels after cardiac surgery was investigated, patients with high blood lactate levels in the postoperative period were found to be hospitalized for a longer duration. The LOS of patients with a 1.3fold higher blood lactate level was found to increase compared with those with normal blood lactate levels [11]. In a study of 1259 patients undergoing cardiopulmonary bypass operation, the relationship between blood lactate levels and LOS was investigated and patients with high lactate levels were found to stay in hospital and the intensive care unit (ICU) for significantly longer than those with normal lactate levels [13]. Similarly, blood lactate levels were found to be higher in patients hospitalized with COPD exacerbation for more than seven days in the present study. Accordingly, in critical settings, blood lactate increases before clinically overt hemodynamic impairment and can be a good tool for the early identification of patients at increased risk of short-term adverse outcomes. The exact mechanism for lactate elevation in critical illness in general is not clearly understood. One view is that lactate elevation is caused by tissue hypoperfusion. However, studies suggested that decreased oxygen utilization also played an important role in lactate elevation in patients with sepsis $[6,11]$.

In a study by Veličković et al., an increase was observed in the postoperative complication rate of patients whose blood lactate levels were measured after elective major abdominal surgery and were seen to be elevated. High lactate levels despite similar postoperative care in all patients was attributed to long hospital stay [14].

In the present study, the blood lactate levels of patients who required NIMV during their hospitalization due to COPD exacerbation were found to be significantly higher than those who did not require NIMV. In a study that included patients admitted to the ED with a diagnosis of systemic inflammatory response syndrome, the risk of organ dysfunction development in 24 hours and hospitalization in the ICU was found to be higher in patients with high lactate levels [15]. In a study including children admitted to the ED with the suspicion of infection, those with high lactate levels were seen to have a higher risk of hospitalization or stay in the ICU. In the same study, high lactate level was further associated with disease severity [16].

Blood lactate level is used as a global indicator of perfusion and oxygenation insufficiency as well as microcirculatory dysfunction. It plays an important role in predicting disease severity, prognosis, and mortality in many critical situations [17].

There are many studies examining the relationship between lactate level and mortality. In a study investigating mortality and blood lactate levels in 33 patients staying in the respiratory ICU, blood lactate levels of non-surviving patients were seen to be significantly higher than those of surviving patients. In the same study, a significant correlation was found between blood lactate level and length of hospital stay [18]. In a review of studies on patients staying in ICUs due to critical conditions such as sepsis, cardiogenic shock, trauma, or respiratory failure, decrease in blood lactate levels during follow-up has been associated with low mortality rates [9]. Although lactate level is a good predictor of disease severity, mortality, and prognosis for patients in ICUs, the relationship between COPD exacerbation and blood lactate level is still not known. In a study of presenting at the ED, blood lactate level was found to be correlated with mortality [19]. Regardless of the underlying cause, the 28-day mortality of patients with high blood lactate levels admitted to the ED was found to be higher than those with normal blood lactate level [20]. The role of blood lactate level in predicting hospitalization period was investigated in a study of 275 patients admitted to the ED due to carbon monoxide poisoning. In a study, blood lactate levels of patients hospitalized for more than three days were found to be higher [21]. Similarly, in the present study, blood lactate levels were found to be high in patients 
hospitalized due to COPD exacerbation for a long duration. Further, it was detected that these patients required non-invasive mechanical ventilation more. In a study performed in an ICU, lactate levels of patients receiving mechanical ventilation support due to acute respiratory distress syndrome were found to be high compared with the lactate levels of the control group [22].

The study has several limitations. First, the study was conducted in a single centre, which limits the generalizability of the results. Second, the sample size was too small and univariate analysis was performed for the factors affecting the LOS, but multivariate analysis could not be performed because of the small number of patients.

In conclusion, lactate levels may become important in clinical practice in the follow-up of patients hospitalized due to COPD exacerbation, and in predicting the duration of hospitalization because it can be measured quickly and easily.

Disclosures: There is no conflict of interest for all authors.

\section{References}

1. Global Strategy for the Diagnosis, Management and Prevention of COPD, Global Initiative for Chronic Obstructive Lung Disease (GOLD). 2017. Available from: http://goldcopd.org

2. Celi BR, MacNee W. Standards for the diagnosis and treatment of patients with COPD: a summary of the ATS/ERS position paper. Eur Respir J. 2004; 23:932-46. https://doi.org/10.1183/09031936.04.00014304

3. Wedzicha JA, Seemungal TA. COPD exacerbations: defining their cause and prevention. Lancet. 2007; 370:786-96. https://doi. org/10.1016/S0140-6736(07)61382-8

4. Seemungal TA, Donaldson GC, Bhowmik A, et al. Time course and recovery of exacerbations in patients with chronic obstructive pulmonary disease. Am J Respir Crit Care Med. 2000; 161:1608-13. https://doi.org/10.1164/ajrccm.161.5.9908022

5. Vernon C, Letourneau JL. Lactic acidosis: Recognition, kinetics, and associated prognosis. Crit Care Clin. 2010; 26:255-83. https://doi.org/10.1016/j.ccc.2009.12.007

6. Revelly JP, Tappy L, Martinez A, et al. Lactate and glucose metabolism in severe sepsis and cardiogenic shock. Crit Care Med. 2005; 33:2235-40. https://doi.org/10.1097/01.CCM.0000181525.99295.8F

7. Bernardin G, Pradier C, Tiger F, Deloffre P, Mattei M. Blood pressure and arterial lactate level are early indicators of short-term survival in human septic shock. Intensive Care Med. 1996; 22:17-25. https://doi.org/10.1007/BF01728326

8. Kurt NG, Orak M, Üstündağ M. The role of lactate clearance on deciding discharge in exacerbation of chronic obstructive pulmonary disease: Retrospective cohort study. J Surg Med. 2018; 2(2):96-98.

9. Vincent JL, Quintairos E, Silva A, Couto Jr L, Taccone FS. The value of blood lactate kinetics in critically ill patients: a systematic review. Crit Care. 2016; 20:257. https://doi.org/10.1186/s13054-016-1403-5

10. Régnier MA, Raux M, Le Manach Y, Asencio Y, Gaillard J, Devilliers C, et al. Prognostic significance of blood lactate and lactate clearance in trauma patients. Anesthesiology. 2012; 117:1276-88. https://doi.org/10.1097/ALN.0b013e318273349d

11. Andersen LW, Holmberg MJ, Doherty M, Khabbaz K, Lerner A, Berg KM, Donnino MW. Postoperative lactate levels and hospital length of stay after cardiac surgery. Journal of Cardiothoracic and Vascular Anesthesia. $2015 ; 29$ (6):1454-1460. https://doi.org/10.1053/j.jvca.2015.06.007

12. Durmuş U, Nurettin ÖD, Pekdemir M, Yılmaz S, Yaka E, Karadaş A, Pınar SG. The value of lactate clearance in admission decisions of patients with acute exacerbation of COPD. American Journal of Emergency Medicine. 2018; 36(6):972-976. https://doi.org/10.1016/j.ajem.2017.11.002

13. Demers P, Elkouri S, Martineau R, Couturier A, Cartier R. Outcome with high blood lactate levels during cardiopulmonary bypass in adult cardiac operation. Ann Thorac Surg. 2000; 70:2082-6. https://doi.org/10.1016/S0003-4975(00)02160-3

14. Jelena Veličković, Ivan Palibrk, Biljana Miličić , Dejan Veličković, Bojan Jovanović, Goran Rakić, Milorad Petrović, Vesna Bumbaširević. The association of early postoperative lactate levels with morbidity after elective major abdominal surgery. Bosn J Basic Med Sci. 2019; 19(1):72-80 https://doi.org/10.17305/bjbms.2018.3186

15. Scott HF, Donoghue AJ, Gaieski DF, Marchese RF, Mistry RD. The utility of early lactate testing in undifferentiated pediatric systemic inflammatory response syndrome. Acad Emerg Med. 2012; 19(11):1276-80. https://doi.org/10.1111/acem.12014

16. Reed L, Carroll J, Cummings A, Markwell S, Wall J, Duong M. Serum lactate as a screening tool and predictor of outcome in pediatric patients presenting to the ED with suspected infection. Pediatr Emerg Care. 2013; 29(7):787-91. https://oi. org/10.1097/pec.0b013e318298389d

17. Okorie ON, Dellinger P. Lactate: Biomarker and potential therapeutic target. Crit Care Clin. 2011; 27(2):299-326. https://doi. org/10.1016/j.ccc.2010.12.013

18. Shalaby A, Khalafallah O, Galal M, Assal HH, Ahmed N. Correlation between serum lactate and other oxygenation indices as a predictor of outcome in respiratory ICU patients. Egyptian Journal of Chest Diseases and Tuberculosis. 2016; 65:695-700. https://doi.org/10.1016/j.ejcdt.2016.04.010

19. B.R. Widgren, M. Grunstra, Serum lactate-useful indicator in emergency care. Läkartidningen. 2011; 108(9):475-477.

20. Danith PA van den Nouland, Martijn C G J Brouwers, Patricia M StassenPrognostic value of plasma lactate levels in a retrospective cohort presenting at a university hospital ED. BMJ Open. 2017; 7:e011450. https://doi.org/10.1136/bmjopen-2016-011450

21. Güzel M, Atay E, Terzi Ö, Demir MC, Erenler AK, Demir MT. The Role of Lactate and Troponin-I Levels in Predicting Length of Hospital Stay in Patients with Carbon Monoxide Poisoning. Clin Lab. 2019; 1;65(5). https://doi.org/10.7754/Clin. Lab.2018.180929

22. Nanda SK, Murthy H. Role of plasma lactate and arterial blood gas as prognostic marker in Acute respiratory distress syndrome patients receiving mechanical ventilation. Biomedical Research. 2011;22(4)

How to cite this article: Seda Beyhan Sagmen, Tugba Naziroglu.Relationship between lactate level and length of hospital stay in patients with a COPD exacerbation. J Clin Med Kaz. 2020; 3(57):19-23 